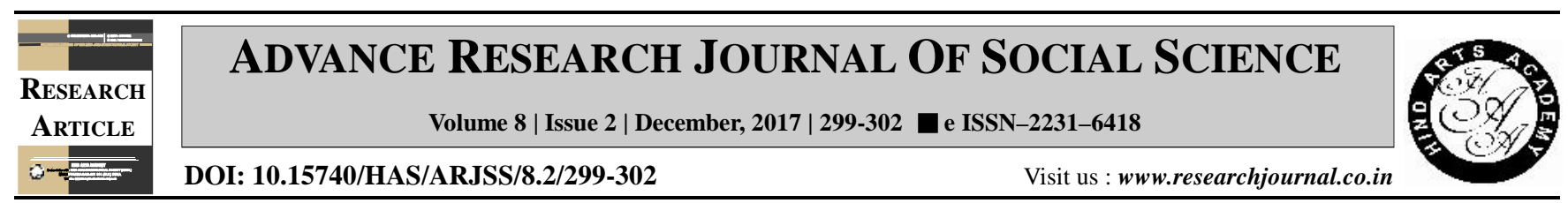

\title{
Transactional analysis of early adolescents
}

Arti Parmar, Pragaya Dashora*, Himakshi Baruah and Milan Punadiya

Department of Human Development and Family Studies, ASPEE College of Home Science and Nutrition, Sardarkrushinagar Dantiwada Agricultural University, PALANPUR (GUJARAT) INDIA

(Email: pragayadashora@ rediffmail.com, himakshibaruah23@gmail.com)

\section{ARTICLE INFO :}

$\begin{array}{lll}\text { Received } & : & 23.09 .2017 \\ \text { Revised } & : & 24.10 .2017 \\ \text { Accepted } & : & 08.11 .2017\end{array}$

KEY WORDS :

Transactional analysis, Early adolescents

HOW TO CITE THIS ARTICLE :

Parmar, Arti, Dashora, Pragaya, Baruah, Himakshi and Punadiya, Milan (2017).

Transactional analysis of early adolescents. Adv. Res. J. Soc. Sci., 8 (2) : 299-302, DOI: 10.15740/HAS/ARJSS/ 8.2/299-302.

*Author for correspondence

\begin{abstract}
Transactional analysis is a unique technique of behaviour modification through which undesirable behaviour can be turned into affirmative and constructive behaviour. The present study was aimed to analyse transactions among early adolescents. The study sample comprised of 240 early adolescents (120 girls and 120 boys) from Government schools of Deesa City. Transactional pattern of girls was found to be better as compared to boys but statistically they were of same order. Reactive style was most preferred where as task managing was least preferred by total respondents. Task managing, adaptive and creative style was preferred by girls whereas boys favoured nurturing, regulating and reactive styles. Boys and girls differ significantly for reactive and creative style. Education, type of school and annual income were significant determinants of TA.
\end{abstract}

